\title{
Tingkat Pengetahuan dan Persepsi Dokter Puskesmas di Kota Bandung terhadap Pengembangan Karir sebagai Dokter Layanan Primer Tahun 2016
}

\author{
Muhammad Ananta Winarto ${ }^{1}$, Elsa Pudji Setiawati², Nita Arisanti² \\ ${ }^{1}$ Fakultas Kedokteran, Universitas Padjadjaran \\ ${ }^{2}$ Departemen Ilmu Kesehatan Masyarakat, Fakultas Kedokteran Universitas Padjadjaran
}

\begin{abstract}
Abstrak
Dokter layanan primer dapat menjadi pilihan dalam pengembangan karir dokter umum di Indonesia. Kehadiran dokter layanan primer menimbulkan pendapat dan sikap dari berbagai pihak. Pendapat dan sikap muncul setelah seseorang memiliki pengetahuan dan persepsi terhadap sesuatu. Penelitian ini bertujuan menggambarkan pengetahuan dan persepsi dokter yang bekerja di puskesmas kota Bandung terhadap dokter layanan primer. Penelitian ini merupakan penelitian potong lintang yang dilakukan pada Bulan September-November 2016 di 73 Puskesmas di Kota Bandung dengan studi desain deskriptif kuantitatif dan kualitatif minor. Data diambil menggunakan kuesioner mengenai pengetahuan dan persepsi terhadap dokter layanan primer yang disebar kepada dokter fungsional yang berada di Puskesmas. Pengambilan sampel dilakukan dengan metode total sampling. Terkumpul data dari 70 dokter fungsional yang berasal dari 57 Puskesmas di Kota Bandung. Hasil analisis data didapatkan bahwa $20,0 \%$ responden memiliki pengetahuan baik, $61,4 \%$ cukup, dan $18,6 \%$ responden kurang. Untuk aspek persepsi, responden yang memiliki persepsi positif dan negatif sama-sama sebesar $50 \%$ terhadap dokter layanan primer. Sebagian besar responden masih belum memiliki pengetahuan yang baik terhadap dokter layanan primer, sehingga disertai masih terdapatnya setengah responden yang memiliki persepsi negatif terhadap dokter layanan primer.

Kata Kunci : Dokter Layanan Primer, Dokter puskesmas.
\end{abstract}

\section{The Knowledge and Perception of Puskesmas doctor in Bandung towards Career Development as a Primary Care Doctor Year 2016}

\begin{abstract}
Primary care doctor can be an option in the career development of general practitioners in Indonesia. The presence of primary care doctor raises opinions and attitudes from various groups. Opinion and attitude exist once a person acquires knowledge, which then leads to the formation of perception, on the matter. This study was to describe the knowledge and perceptions of general practitioners in Bandung towards primary care doctor. Across-sectional study of 73 Public Health Centers (Pusat Kesehatan Masyarakat/ "Puskesmas") in Bandung was performed in SeptemberNovember 2016, using descriptive quantitative and minor qualitative research design. Data were collected by employing questionnaire on the knowledge and perception towards primary care doctor, involving the functional doctors in the Public Health Centers. Samples were drawn through total sampling. Data from 70 functional doctors of 57 Public Health Centers in Bandung were gathered. Analysis of the findings showed that 20\% of the respondents have good knowledge around primary care doctor, 61.4\% moderate, and $18.6 \%$ poor. As for the perception category, the number of respondents who have positive and negative perceptions on primary care doctor are $50 \%$ respectively. The results suggest that majority of the respondents are yet to have good knowledge about primary care doctor, and hence, the negative perception on primary care doctor still circulating around half of the respondents.
\end{abstract}

Keywords : Primary Care Doctor, Public health.

Korespondensi:

Muhammad Ananta Winarto

Fakultas Kedokteran Universitas Padjadjaran

Jl. Raya Bandung-Sumedang KM 21 Jatinangor, Sumedang

Mobile : 082214620742

Email : anantawinarto@yahoo.co.id 


\section{Pendahuluan}

Terdapat berbagai permasalahan kesehatan di Indonesia terutama di fasilitas pelayanan kesehatan tingkat primer, berupa kurangnya sarana, prasarana serta tenaga kesehatan. ${ }^{1}$ Untuk menghadapi permasalahan kesehatan tersebut dibutuhkan peningkatan kualitas dari pelayanan kesehatan tingkat primer. ${ }^{2}$ Peningkatan kualitas dapat berupa pemenuhan sarana dan prasarana serta peningkatan secara kuantitas dan kualitas tenaga kesehatan, sebagai contoh, Denmark dan Belanda yang memiliki kualitas sistem kesehatan yang baik menitikberatkan pelayanan kesehatan kepada seorang General Practitioner(GP) sebagai gatekeeper. General Practitioner adalah dokter spesialis dalam bidang generalis yang menjadi garda pertama dalam pelayanan kesehatan di tingkat layanan primer dan telah melalui pendidikan formal setelah pendidikan dokter.,

Pemerintah Republik Indonesia membuat kebijakan strategis dalam Rancangan Pembangungan Jangka Menengah Nasional (RPJMN) 2015-2019 tentang penguatan layanan primer yang berisi peningkatan kualitas tenaga kesehatan, dimana peningkatan kualitas ini dapat dilakukan dengan peningkatan kompetensi. ${ }^{1}$ Peningkatan kompetensi di Indonesia dapat dilakukan dengan meningkatkan tingkat Kerangka Kualifikasi Nasional Indonesia (KKNI) dari tingkat KKNI 7 yang merupakan basic medical doctor ke tingkat KKNI 8 atau post-graduate profesi kedokteran. ${ }^{4}$

Seseorang yang bekerja pastinya memiliki beberapa tujuan selama bekerja. Terkadang bagi seseorang yang semula tujuannya hanya berupa memperoleh penghasilan, lambat laun tujuannya akan berubah untuk memperoleh jenjang karir yang lebih baik. Dengan meningkatkan jenjang karir berarti seseorang memikirkan masa depannya dan secara otomatis akan meningkatkan kesejahteraan, dan harga dirinya. ${ }^{15}$ Didalam Sistem Kesehatan Nasional (SKN) terdapat 3 tingkatan dalam upaya kesehatan, yaitu tingkat layanan primer, sekunder, dan tersier. ${ }^{14}$ Pada sistem pendidikan kedokteran di Indonesia belum terdapat pengembangan karir bagi dokter yang memiliki minat untuk bekerja di layanan primer. Pengembangan karir dokter di pelayanan kesehatan primer juga diperlukan karena ilmu kedokteran terus berkembang pesat termasuk bidang layanan primer dan juga untuk meningkatkan kesejahteraan, dan harga diri dokter yang berminat berkarir di layanan primer. Sebagai syarat penambahan karir di layanan primer diperlukan adanya sebuah pendidikan formal, sebagaimana ilmu kedokteran pada layanan sekunder dan tersier, seperti spesialis ilmu penyakit dalam, bedah, obstetrik dan ginekologi yang telah diajarkan pada program studi dokter, namun untuk menjadi ahli dalam bidang tersebut, dokter harus mengambil program pendidikan spesialis dan sub-spesialis lagi. ${ }^{12} \mathrm{Hal}$ ini sejalan dengan kebijakan World Federation Medical Education (WFME) yang membuat jenjang pendidikan menjadi 3 jenjang, Basic Medical Education (BME), Post-graduate Medical Education (PME), dan Continuing Professional Development (CPD). ${ }^{5}$ Sama halnya dalam bidang ilmu kedokteran layanan primer, dokter dapat mengambil program pendidikan dokter layanan primer (DLP) sebagai pengembangan karir.

Program pendidikan DLP memunculkan pendapat-pendapat dan sikap dari berbagai pihak, khususnya dari kalangan profesi kesehatan. Ada pihak yang mendukung dan juga yang menolak. Pendapat atau sikap tersebut telah melalui proses dimana awalnya terpaparnya seseorang terhadap stimulus-stimulus yang masuk melalui panca indranya, baik mendapat informasi dari orang lain atau media maupun melihat dan mendengar langsung keadaan kesehatan dan pendidikan kedokteran di Indonesia sekarang. Selanjutnya stimulus tersebut akan diterima oleh otak dan menjadi pengetahuan seseorang. Proses selanjutnya adalah terbentuknya persepsi apakah program DLP ini cocok atau tidak sebagai pengembangan karir sehingga seseorang dapat menentukan sikap untuk menerima atau menolak program DLP ini.?

Pada saat ini, belum ada data yang menggambarkan pengetahuan dan persepsi dokter di Puskesmas terhadap DLP sebagai pengembangan karir. Dokter Puskesmas merupakan calon mahasiswa dari program DLP yang memiliki minat bekerja di layanan primer sebagai karirnya. Tujuan penelitian adalah mendapat gambaran pengetahuan dan persepsi dokter puskesmas di Kota Bandung terhadap pengembangan karir sebagai dokter layanan primer. Penelitian ini diharapkan dapat dijadikan sebagai perbandingan untuk penelitian serupa dan salah satu bahan masukan untuk perbaikan program pendidikan DLP.

\section{Metode}

Penelitian ini merupakan penelitian potong lintang yang dilakukan pada Bulan SeptemberNovember 2016 di 73 Puskesmas di Kota Bandung dengan studi desain deskriptif kuantitatif dan kualitatif minor. Subjek penelitian adalah semua dokter umum yang bekerja di puskesmas dengan kriteria inklusi yaitu minimal sudah bekerja minimal 1 tahun dan berada di 
puskesmas saat masa penelitian, dan kriteria eksklusi berupa kepala puskesmas dan tidak bersedia mengisi kuesioner. Sumber data pada penelitian ini adalah sumber data primer yang diperoleh secara langsung dari hasil kuesioner pada responden yang bersedia untuk mengerjakan kuesioner serta sedikit wawancara yang dapat dijadikan perbandingan sebagai metode kualitatif minor. Teknik pemilihan sampel (sampling) yang digunakan dalam penelitian ini adalah Total sampling. Tujuan dan cara pengambilan data penelitian ini telah mendapat izin dari komite etik Fakultas Kedokteran Unpad dengan nomer registrasi 0116070711 dan Dinas Kesehatan Kota Bandung dengan nomer 070/10091 - Dinkes.

Instrumen yang digunakan dalam penelitian ini adalah kuesioner yang telah melalui proses validasi dan reliabilitasi mengenai pengetahuan dan persepsi. Pertanyaan pengetahuan berjumlah 11 buah (wajib tidaknya, jenjang, waktu, calon mahasiswa, tingkat KKNI, kompetensi, tahapan, sistem pembayaran, ranah kerja pendidikan DLP, dan program DLP di luar negeri) dan pertanyaan persepsi berjumlah 10 buah (latar belakang, DLP merupakan solusi, ketertarikan, konsep, waktu, sosialisasi, ranah kerja, kehadiran DLP, berniat untuk mendaftar program DLP).

Analisis data dilakukan dengan menggunakan perangkat lunak statistik komputer. Penilaian konten pengetahuan dilakukan dengan menggunakan skala Guttman. Untuk menilai persepsi dilakukan dengan menggunakan skala Likert, yaitu terdapat nilai 1-5 pada setiap jawaban pertanyaan. Kemudian dikategorikan dengan perhitungan menurut Saifuddin Azwar (2005) dan didapatkan klasifikasi nilai untuk kueisoner pengetahuan, yaitu nilai 'baik' bagi yang menjawab 8-11 pertanyaan benar, 'cukup' untuk 4-7 pertanyaan, dan 'kurang' untuk 0-3 pertanyaan benar dan klasifikasi nilai untuk kuesioner persepsi adalah persepsi 'positif' untuk nilai lebih dari sama dengan rata-rata $(\geq 27)$ dan 'negatif' untuk nilai kurang dari rata-rata $(<27) .{ }^{8}$

\section{Hasil}

Sampel yang didapat dari penelitian ini berjumlah 70 dokter fungsional $(55 \%$ dari total 127 dokter fungsional) dari 57 Puskesmas (78\% dari total 73 puskesmas) di kota Bandung. Dari total 157 dokter yang bekerja di puskesmas, 30 diantaranya merupakan kepala puskesmas.

Pengelompokan riwayat kerja dalam hasil penelitian ini diambil dari sistem Recognized Prior Learning (RPL) pada program pendidikan DLP. Berikut adalah tabel yang menjabarkan karakteristik responden.
Berdasarkan hasil analisis data, sebagian besar responden $61,4 \%(n=43)$ memiliki pengetahuan 'cukup' mengenai DLP. Gambaran pengetahuan reponden dapat dilihat pada gambar 1 dan gambaran lebih rinci mengenai pengetahuan responden dapat dilihat pada gambar 2 .

\section{Tabel 1 Karakteristik Responden}

\begin{tabular}{|c|c|c|}
\hline Karakteristik & $\underset{\text { (n) }}{\text { Jumlah }}$ & $\begin{array}{c}\text { Persentase } \\
(\%)\end{array}$ \\
\hline \multicolumn{3}{|l|}{ Jenis kelamin } \\
\hline Pria & 12 & 17.1 \\
\hline Wanita & 58 & 82.9 \\
\hline \multicolumn{3}{|l|}{ Usia (tahun) } \\
\hline$<30$ & 19 & 27.1 \\
\hline $30-39$ & 37 & 52.9 \\
\hline $40-49$ & 8 & 11.4 \\
\hline$\geq 50$ & 6 & 8.6 \\
\hline \multicolumn{3}{|l|}{ Status Pernikahan } \\
\hline Menikah & 57 & 81.4 \\
\hline Tidak Menikah & 13 & 18.6 \\
\hline \multicolumn{3}{|l|}{ Riwayat kerja (tahun) } \\
\hline$<5$ & 26 & 37.1 \\
\hline $5-10$ & 27 & 38.6 \\
\hline$>10$ & 17 & 24.3 \\
\hline \multicolumn{3}{|l|}{ Status Kepegawaian } \\
\hline PNS & 35 & 50.0 \\
\hline PTT Daerah & 34 & 48.5 \\
\hline PTT Pusat & 1 & 1.5 \\
\hline \multicolumn{3}{|l|}{ Pendidikan Terakhir } \\
\hline Pendidikan dokter & 65 & 92.9 \\
\hline Magister S2 & 5 & 7.1 \\
\hline Total & 70 & 100 \\
\hline
\end{tabular}

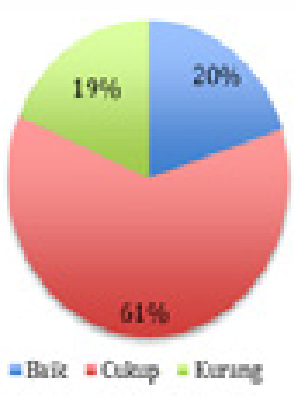

Gambar 1 Gambaran pengetahuan responden 


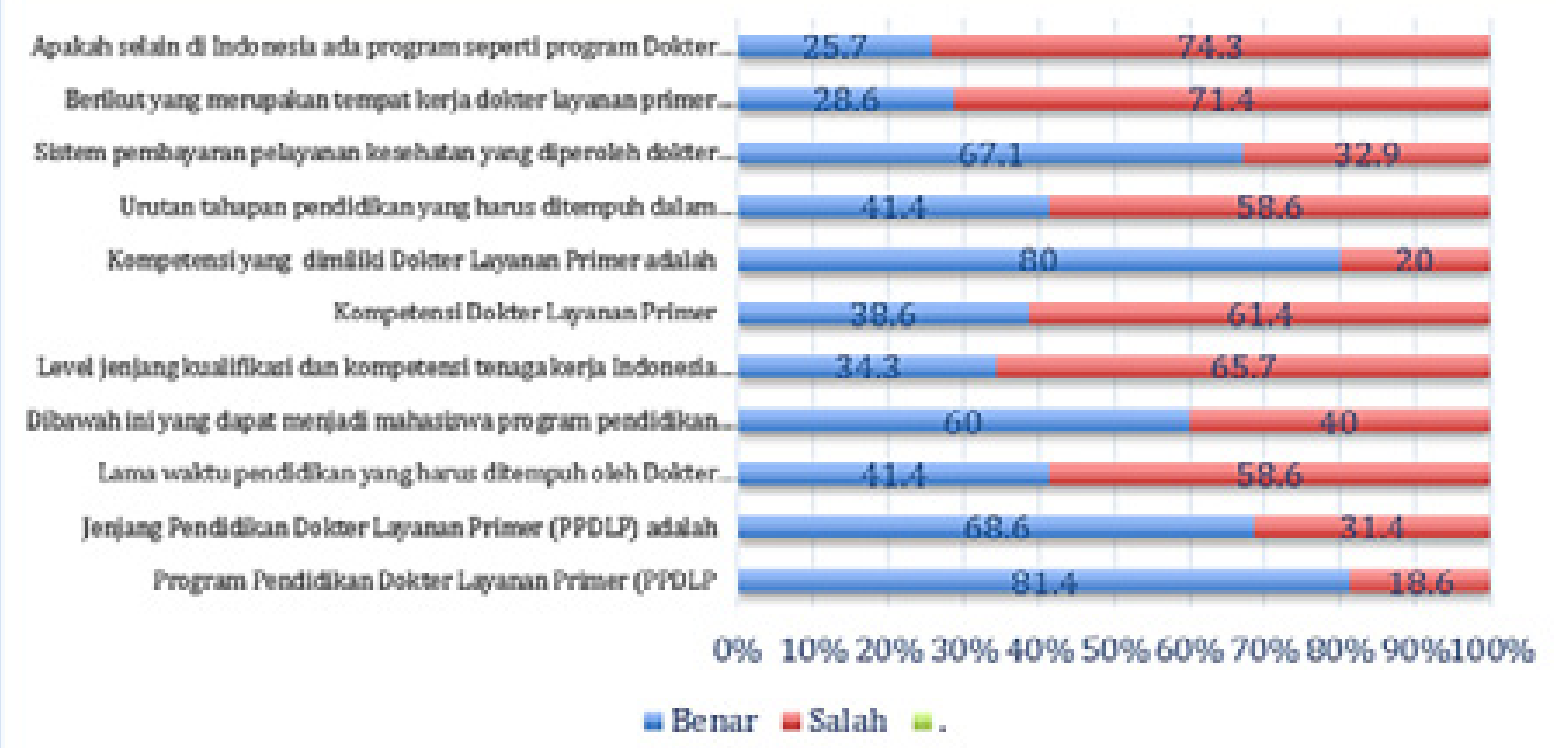

Gambar 2 Gambaran lebih rinci pengetahuan responden

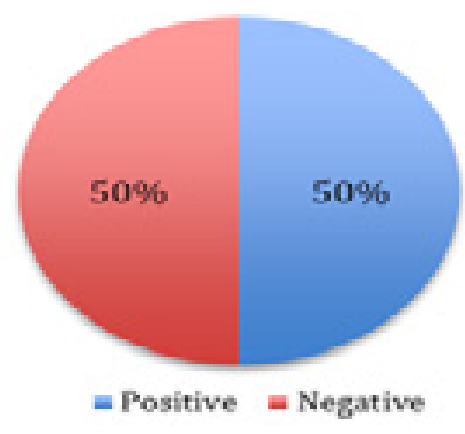

\section{Gambar 3 Gambaran persepsi responden}

Berdasarkan hasil penelitian, jumlah responden yang memiliki persepsi positif dan negatif sama besar $(50 \%)$ terhadap DLP. Gambaran mengenai persepsi responden dapat dilihat pada gambar 3 dan gambaran lebih rinci mengenai persepsi responden dapat dilihat pada gambar 4 .

\section{Pembahasan}

Berdasarkan hasil penelitian, dokter di Puskesmas kota Bandung sudah memiliki pengetahuan yang cukup baik mengenai dokter layanan primer, namun belum dilihat secara terperinci. Persepsi dokter di Puskesmas kota Bandung sama besar untuk kedua kategori positif dan negatif. Untuk mengetahui gambaran lebih terperinci mengenai pengetahuan dan persepsi dokter Puskesmas di kota Bandung mengenai DLP, akan dibahas dalam beberapa pertanyaan dan dihubungkan dengan karakteristik responden.

Setengah dari responden masih berstatus pegawai tidak tetap (PTT), artinya responden ini masih bebas memilih karir dalam bidang kedokteran. Dilihat dari hasil penelitian yang menunjukkan bahwa pengetahuan responden adalah cukup, seharusnya pengetahuan tentang DLP dapat meningkatkan minat/intensi terhadap program pendidikan DLP (PPDLP). Namun dari hasil penelitian juga didapatkan bahwa masih sedikit sekali responden yang berminat untuk mendaftar PPDLP. Hal ini sejalan dengan penelitian Lambert $\mathrm{T}$ dkk, yang menunjukkan bahwa kurang dari 1/3 lulusan dokter ingin berkarir di bidang generalis atau menjadi GP. Hal ini disebabkan oleh berbagai faktor dalam pemilihan karir, yang paling berpengaruh yaitu antusiasme dan komitmen mendasar dalam bidang tersebut serta ekspektasi kondisi dan durasi pekerjaan yang akan dipilih. ${ }^{11}$

Sebagian besar responden sudah mengetahui bahwa PPDLP adalah tidak wajib. Namun dari hasil wawancara yang telah dilakukan, banyak yang beranggapan bahwa PPDLP akan menjadi wajib pada beberapa tahun kedepan terutama bagi mahasiswa pendidikan dokter dan juga dokter yang bekerja di puskesmas. Responden merasa iba pada mahasiswa calon dokter yang akan menempuh pendidikan dokter. Padahal pada dasarnya, PPDLP merupakan program post-graduate medical education (PGME) yang terdapat dalam tingkatan klasifikasi pendidikan 


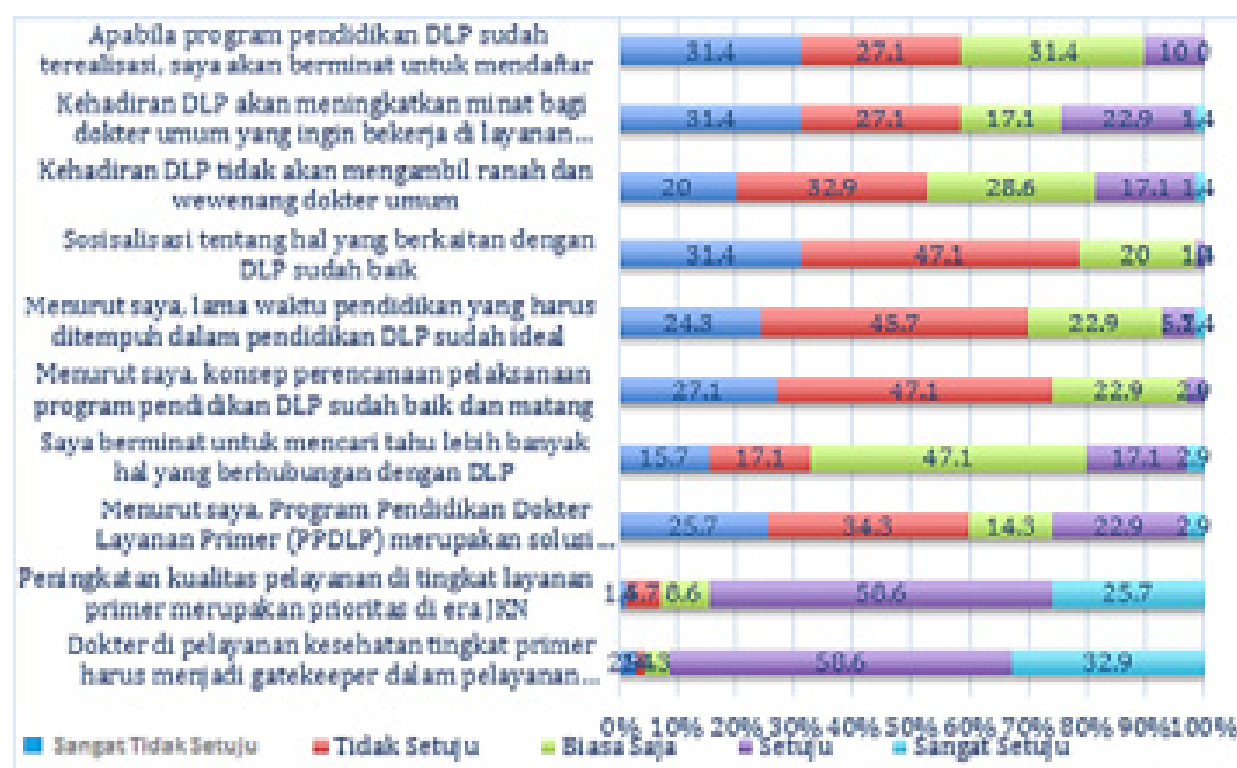

Gambar 4 Gambaran lebih rinci persepsi responden

kedokteran oleh WFME. Sama halnya dengan spesialis lainnya, DLP dapat dijadikan pilihan untuk pengembangan karir dokter umum dan bukan sebuah hal yang wajib. ${ }^{5,6}$

Pengetahuan responden mengenai jenjang pendidikan sudah cukup baik, dilihat dari mayoritas reponden sudah menjawab bahwa 'jenjang pendidikan dokter layanan primer adalah program profesi spesialis/setara spesialis' walaupun masih ada sebagian yang beranggapan bahwa jenjang pendidikan DLP adalah magister S2. Dari hasil wawancara yang telah dilakukan, sebagian responden berpendapat bahwa seharusnya untuk meningkatkan kompetensi dokter umum terutama di bidang layanan primer tidak diperlukan lagi jenjang pendidikan formal, karena responden merasa sudah cukup dengan mengikuti pengayaan dan pelatihan seperti yang selama ini telah dilakukan. Menurut Perhimpunan Dokter Layanan Primer Indonesia (PDLPI), PPDLP tidak cukup dimasukkan kedalam program pendidikan dokter karena sebagai suatu disiplin ilmu tersendiri, seperti hal nya di negara lain, contohnya Denmark dan Belanda., ${ }^{3,12,13}$ Hal ini terbukti dari hasil penelitian yang mendapatkan bahwa pengetahuan responden mengenai ada tidaknya program seperti DLP di luar negeri yang masih rendah.

Pengetahuan responden mengenai kompetensi DLP masih kurang, dilihat dari sebagian besar responden menjawab bahwa kompetensi dokter layanan primer sama dengan dokter umum. Dari hasil wawancara yang telah dilakukan, sebagian besar beranggapan bahwa 'kompetensi DLP telah didapatkan semua dalam pendidikan dokter umum dan juga bisa didapatkan dari pelatihanpelatihan untuk dokter umum'. Pengetahuan mengenai area kompetensi DLP sudah baik. Hasil wawancara didapatkan bahwa, sebagian besar responden menganggap bahwa PPDLP hanya akan meningkatkan kompetensi dalam hal kuratif atau keterampilan klinis saja, seperti dapat dilakukannya operasi usus buntu di puskesmas dan akan mengurangi angka rujukan ke rumah sakit. Menurut PDLPI, peningkatan kompetensi keterampilan klinis hanya merupakan salah satu dari 7 kompetensi dokter layanan primer. ${ }^{12}$

Pengetahuan mengenai teknis pelaksanaan DLP dapat dilihat dari pertanyaan lama waktu atau durasi pendidikan, calon mahasiswa, dan tahapan PPDLP. Pengetahuan mengenai durasi PPDLP masih kurang, dilihat dari mayoritas responden menjawab salah. Pada dasarnya lama waktu PPDLP adalah 3 tahun, sedangkan untuk calon mahasiswa yang telah bekerja lebih dari 5 tahun pada layanan primer bisa mengikuti sistem RPL sehingga waktu pendidikan yang akan ditempuh akan disesuaikan kembali. Pengetahuan mengenai tahapan PPDLP juga masih kurang. Namun pengetahuan mengenai calon mahasiswa yang dapat mendaftar DLP sudah cukup baik dilihat dari mayoritas responden menjawab bahwa 'seluruh dokter yang telah memiliki surat tanda registrasi KKI merupakan calon mahasiswa PPDLP'. ${ }^{2}$

Berikut mengenai 3 pertanyaan yang berisi DLP sebagai pengembangan karir, yaitu tingkat KKNI, sistem pembayaran, dan ranah kerja DLP. Pengetahuan mengenai sistem pembayaran yang diperoleh dokter layanan primer sudah 
baik, sedangkan pengetahuan mengenai tingkat KKNI dan ranah kerja masih kurang dilihat dari mayoritas responden menjawab salah pada kedua pertanyaan tersebut. Hal ini sejalan dengan persepsi negatif responden bahwa sebagian besar tidak setuju dengan pernyataan dokter layanan primer tidak akan mengambil ranah dan wewenang dokter umum di puskesmas. Menurut hasil wawancara yang didapat bahwa sebagian responden tidak mengetahui ranah kerja DLP dan berfikir sama saja dengan dokter umum. Kurangnya pengetahuan mengenai ranah kerja DLP ini tentunya akan menurunkan minat responden terhadap DLP. Hal ini sejalan dengan penelitian Lambert $\mathrm{T}$ dkk yang mengatakan ada berbagai faktor dalam pemilihan karir, yang paling berpengaruh yaitu antusiasme dan komitmen mendasar dalam bidang tersebut serta ekspektasi kondisi dan durasi pekerjaan yang akan dipilih. ${ }^{11}$

Dapat disimpulkan bahwa pengetahuan responden mengenai DLP sudah cukup, namun setelah mengetahui secara terperinci masih terdapat beberapa ketidaktahuan responden mengenai DLP. Dari hasil wawancara yang telah dilakukan, hanya sedikit responden yang telah mendapat sosialisasi dari kementerian kesehatan RI, responden lain mendapatkan sosialisasi dari organisasi kesehatan, media, teman sejawat, bahkan ada yang belum pernah mendapat sosialisasi sama sekali. Hal ini sejalan dengan persepsi negatif reponden yang sebagian besar tidak setuju bahwa sosialisasi tentang hal yang berkaitan dengan DLP sudah baik. Diikuti dengan persepsi responden mengenai lama waktu dan konsep PPDLP juga cenderung negatif. Hal ini menunjukkan bahwa sosialisasi mengenai DLP masih sangat kurang. Hasil ini dapat dijadikan sebagai evaluasi kepada stakeholder terkait untuk meningkatkan sosialisasi tentang dokter layanan primer secara resmi agar tidak terjadi salah informasi dan menyebabkan persepsi negatif sehingga menurunkan minat responden untuk mencari tahu lebih banyak hal mengenai DLP.

Peminatan responden terhadap program DLP pada awal perjalanannya tergolong rendah, dapat dilihat dari sebagian besar responden tidak berminat mengikuti PPDLP. Kurangnya peminatan terhadap PPDLP ini tentu telah dipengaruhi oleh masih kurangnya beberapa pengetahuan mengenai DLP dan persepsi setengah responden yang negatif terhadap DLP. Ini sesuai dengan theory of reasoned action yang mengatakan minat atau intensi seseorang melakukan suatu perilaku dipengaruhi oleh sikap, norma subjektif dan persepsi terhadap suatu perilaku. pengetahuan yang dimiliki diri maupun orang lain yang dikenal individu dapat meningkatkan ataupun menurunkan persepsi individu dalam melakukan suatu perilaku. ${ }^{9}$

Masih terdapat dokter di populasi yang tidak dapat menjadi responden penelitian dikarenakan tidak bersedia dan tidak dapat dijumpai selama pengambilan data. Hal ini menjadi keterbatasan pada penelitian ini, karena mungkin saja dapat mempengaruhi hasil penelitian. Kesimpulan yang dapat ditarik dari penelitian ini adalah sebagian besar responden masih belum memiliki pengetahuan yang baik terhadap DLP, disertai masih terdapatnya setengah responden yang memiliki persepsi negatif terhadap dokter layanan primer. Saran dari penelitian ini adalah pentingnya meningkatkan sosialisasi secara resmi kepada individu dan institusi yang terkait dengan DLP.

\section{Daftar Pustaka}

1. Kementrian Kesehatan RI. Rencana Strategis Kementrian Kesehatan Tahun 2015-2019. Jakarta: Kementrian Kesehatan RI; 2015.

2. Depkes P, Wonodirekso S, Pattiradjawane D. Karir Dokter Layanan Primer dalam Rangka Mencapai Target "MDGs .” 2010;101-6.

3. Pedersen K, Andersen J, Søndergaard J. General practice and primary health care in Denmark. J Am Board Fam Med. 2012;25 Suppl 1(April):34-8.

4. Pedoman B, Pengantar K. Indonesian Qualification Framework. 2010

5. World Federation for Medical Education. Basic Medical Education: WFME Global Standards for Quality Improvement. 2007;36.

6. Depkes P, Wonodirekso S, Pattiradjawane D. Karir Dokter Layanan Primer dalam Rangka Mencapai Target " MDGs .” 2010;101-6.

7. Walgito B. Pengantar psikologi umum. Yogyakarta: Andi Offset. 2004.

8. Azwar S. Penyusunan Skala Psikologi. 2005;187-96.

9. Ajzen I. The theory of planned behavior. Organ Behav Hum Decis Process. 1991;50(2):179-211.

10. Vidiawati D. Dokter Layanan Primer: Upaya Mengejar Keterlambatan Pergerakan Peningkatan Kualitas Layanan Primer di Indonesia. 2014;2(3).

11. Lambert T, Goldacre R, Smith F, Goldacre MJ. Reasons why doctors choose or reject careers in general practice: Br J Gen Pract. 2012;(December):851-8.

12. Tim Penyusun. Frequently ask question. Dokter Spesialis Layanan Primer. 2015;

13. Ten Cate O. Medical education in The 
Netherlands. Med Teach. 2007;29(8):752-7.

14. Presiden RI. Peraturan Presiden Republik Indonesia No. 72 Tahun 2012 Tentang Sistem Kesehatan Nasional. 2012;91.

15. Manajemen Sumber Daya Manusia (Teori dan Praktik). 1st ed. Jakarta: Rajawali Pers; 2016. 148-149 p. 